\title{
The Brain Drain And Human Rights
}

\author{
Aisyah Wardatul Jannah \\ Law Faculty of Mataram University \\ St. Majapahit No. 62 Mataram 83125, Telp. (0370), 633035. \\ E-mail:w.aisyah47@unram.ac.id
}

\begin{abstract}
The terms of brain drain refers to the movement of the skilled people from less developed country to the developed country caused by several factors such as politic unstability, poverty and development problem in the source country in order to seek out for the new opportunity and better quality of life in the receiving country. Since the movement of the brain have increased year by year, it is arises more development problem to the source country in lack of health care acces, poverty continuously and even died. The study resource of this essay conduct from the library, journal and internet resources, to examine the definition and describe the impact which caused by the brain drain. As the consequences, it is resulted that the brain drain has a negative impact to the resource country but in the other hand it has positive impact as well, further it is qualified that the brain drain have a strong relation with the human rights and have arises question does this brain drain can be blamed for the development problem in source country.
\end{abstract}

Keywords: the brain drain, development,poverty, human rights.

\section{INTRODUCTION}

Brain drain known as one of international development issues, where the skilled people migrate because of the lack development of the resource country. The fact shows that every year there is significant number of health workers professional migrate from developing area to the developed area, they are migrate caused of many reason such as; cannot survive from the poverty, seek out for the better job, better salaries, really want to have better standard of living and so forth.

The statistic shows the data of developed countries which they are migrate to Australia, Canada, Germany, UK and USA and most of the immigrant are from developing countries with dominance of Asian countries and Africa. According to the WHO report in 1970s, published that 40 country study on the magnitude and flow of the health professionals and close to $90 \%$ of all migrating physicians were moving to those five developed countries as 
mentioned above. ${ }^{1}$

This phenomenon called medical brain drain, this term indicated that the immigrants comes from educated people which they are have a skill as a professional and migrate to the developed area seeking for a new opportunity and better quality of life. And the most reason is they are looking for high salary which they can get more than in the country of origin where they are born. As this happen, it is arises issue that the brain drain giving an impact to the country of origin even though in another side they are contributed positive contribution to the receiving country and the country of origin.

Particularly, the country of origin have spend a lot of amount of money to educated the health worker but then they subsequently migrate, while some workers return to their homeland, most of them stay abroad and soon they are followed by their families to stay in the receiving country.for example in Africa, regarding to the IOM report, 20.000 health care workers have been emigrating each year since 1990, with only a small percentage of workers returning to Africa. ${ }^{2}$ It is followed by the statement of Dr. Barker while he warned his foreign colleagues, said that “ in 25 years Africa will lost all of their brain drain”.

Regarding to the brain drain impact, it is related the issues with the human rights issues, which arises a new question: "does the brain drain violate human rights ?" while they are got the better quality of life and the source population can't get better health care in the country of origin and impact the health care system in the country of origin. This question comes up with the fact that happen in Sub Sahara Africa (SSA) which there are 11 countries without medical schools and 24 have only one. this situation compounded by lost skilled of the medical teacher and the health care professional. ${ }^{3}$

\section{ANALYSIS AND DISCUSSION}

\section{The Brain Drain As International Development Issue}

Generally, development implications always refer to the better quality of life, but actually it is more than that, it is more than improvements people in wellbeing, but it is describe the capacity of the system to provide the circumstances for that continued wellbeing. In this regard, the system means the government in order to provide the better

\footnotetext{
${ }^{1}$ Sunitadodani, Ronald E laporte, Brain drain from developing countries : how can brain drain be converted into wisdom gain? Accessed at http://www.ncbi.nlm.nih.gov/pmc/articles/PMC1275994/ 08.06.2016

2 Amy Schnidman, The Global Effects Of The Brain Drain on health care system, Vol 3, Georgetown university, 2006, accessedat https://blogs.commons.georgetown.edu/journal-of-health-sciences/issues-2/previousvolumes/vol-3-no-1-march-2006/the-global-effects-of-the-brain-drain-on-health-care-systems/. 08.06.2016. ${ }^{3}$ Ibid
} 
quality of live to the people today and tomorrow.

There is the terms of sustainable development, that the policy and regulation by the government is going to guarantee the people environment continuously, particularly for the developing country wishing to put their economy and society onto a path of faster development and for outsiders who want to help that process.

The meaning of development from the traditional welfare economics saying that it is concern to the income as the main measure of wellbeing, and in 1980 it is showed that poverty involved a wider range of deprivations in health, education and living standards which were not captured by income alone. ${ }^{4}$

Poverty is one of the issue under international levels which until today every country trying to resolved. Another issues under development is The Brain Drain. This also derived from the poverty where the people wants to help themselves instead the country might can do. When people think that the country cannot help them out from the poverty, the corruption, politic unstability push the people leave. If they have the skilled it is better for them to migrate to the developed area since this country provide job, new opportunity, better salary and safety.

Human development also about give people more freedom and opportunity to get value lives. This means developing people's abilities and giving them chance to use the skill. However it will be useless if the country do not provide any job and fair salary. Further, the globalization bring the people of easiest acces to go abroad, whether for holiday or even for job, as Ban Ki Moon (secretary general of United Nations) stated that :

"we are entering an age of mobility, when people well cross borders in even greater numbers in pursuit of opportunity and a better life. They have the potential to chip away at the vast inequalities that characterize our time, and accelerate progress through put the developing world". 5

According to Ban Ki Moon it is true that the globalization have given the acces and open a new way for the people to travel around the world. Migration became another option for the people who cannot gain any opportunity and stuck in the unsafety situation in their country, while the developed country offered an employment, high salary, better facilities and above all is safety. No wonder the people be in situation that push them to migrate to

${ }^{4}$ Owen Barde, What is development?, Center for Global development, http www.cgdev.org accessed at 06.06.2016

5Brian Keeley, (2009), International Migration (The human face of Globalization), OECD publishing, p. 4. 
sense the advantages that they may gain in the receiver country.

Most people in developing country suffer some common issues such as war that will cause poverty, disease, lack of health care acces, clean water crissis, malnutrition, epidemic of disease, working children, unstabil politic. The country they lived in do not guarantee all of those appropriatiness.

It is ironic, how the poverty can caused people into one disaster to another scheme of disaster, and no one can help them until they are in condition tried to change it from smallest area, let alone to have better standard of living but only to survive. New york times magazine on 06 june edition has proclaim a fact from a million fact that's happen to the victims of war, one of it is Ahmad an 12 years old of Syrian child which migrate to turkey and working at textile factory in Istanbul as the primary breadwinner for his family. The report stated that over one million Syrian children live in turkey and thousand of them like Ahmad are in sweatshops, factories or vegetable fields instead of classroom, members of a lost generation who have been robbed of their youth war. ${ }^{6}$

Back then, while we talked about the skilled people which derived to migrate it also shows the phenomenon that unskilled people also migrate if they are in condition that push them to do so. There are two theory describe the cause why people migrate, there are push and pull factors.

1. Push factors : this factors are motivated by the peoples should move voluntarily, particular circumstances push them to decide migrate to avoid the risk caused by the conflict, war, drought, poor economic activity and lack of job opportunities. While they are needed to feed their families and want to have prosperous life and want to survive.

2. Pull factors : attract the people to leave their country, which the people migrate cause of known as the place utility, the destination country provide the facility which the migrant could get if they are moving there. The promise of a better life are pull the people to migrate, very often the peoples consider to migrate because its near jurisdiction. Furthermore some migrant migrate for education reason, which determine they are migrate to get new experiences and facility. ${ }^{\mathrm{i}}$

There are two type of immigrant, that are skilled and unskilled people and Brain Drain refer to the skilled immigrant. They come up with the skill and they are excluded from illegal immigrant (as the illegal immigrant mostly related with the unskilled immigrant),

${ }^{6}$ Ceylanyeginsu, in turkey a Syrian child has to work to survive, accessed at www.nytimes.com 06.06.2016. 
mostly they work in the health care institutions and give them the permit of stay or work. HHR (health human resource) reported an example of migration by the skilled people in SSA (Sub Sahara Africa). SSA suffered lack of health care workers because they usually migrate to developed area, for example Canada, America and others. Fact shows that SSA partially a result of the significant burden on HIV/AIDS. The health care worker migrate because of fear of infection, burnout, absenteism, heavy workloads and stress affect productivity. This reason then derived the health care workers in Malawi, Zambia and Zimbabwe to migrate in order to avoid and afraid of contracting by the HIV/AIDS disease. ${ }^{7}$

\section{What Is Brain Drain?}

The terms brain drain briefly refers to the emigrate of educated people and skilled people from one country to another, the brain drain terms was defines to describe the migration of British engineers and scientist to the United states, but now this term has lost its strong connotation moved to the definition as mentioned below. ${ }^{8}$

The brain drain divided into 3 types, first is the movement of the people between developed countries to developed countries, from developing to developed countries, and between developing countries to developing countries. Those types has causal link between them which can be describe in example: from developed country A to richer developed country may cause brain drain to A from developing country $\mathrm{C}$, which in turn may induce brain drain from developing country D to C. ${ }^{9}$

Although most of this phenomenon occurred between from the developing countries to the developed countries, particularly the health brain drain in the developing country which are they ill motivated, in the country of origin they get the poorly paid, poorly equipped and have limited career opportunities. In turn, lead them to consider migrate out of the poor working conditions.

The brain drain also can be describe in example as the foreign student, where peoples migrate to study abroad, they are seeking for new experiences and facility which they can get in in the developed country, they typically found a job after graduated and residing in the receiving country for more than a years followed the requirement of job contract. Some other way, skilled people study in the country of origin but because of the push factors which

${ }^{7}$ Jonathan Crush, The brain drain of health professionals from Sub Saharan Africa to Canada (series editor), SAMP, p. 30.

${ }^{8} \mathrm{~S}$ Watanabe, The brain drain from Developing to Developed Countries, p. 1

${ }^{9}$ Ibid 
included the poor salary and limited carrier opportunity push them to migrate seek out for a better chances. Even though the country of origin have spend the time and money to educated these people, it does not guarantee that they may going back to the country of origin, despite that their family follow them to migrate to the receiving country.

\section{Medical Brain Drain}

As mentioned above, the brain drain refers to the departure peoples migrate from one country to another, but most of them moved from the developing countries to the developed countries, particularly medical brain drain, since arises problem to the impact of health care system in the country of origin when their skilled health professional decided to migrate to the developed area which can promises for a better life. The medical brain drain applied specifically to health care workers, a group encompassing not only doctors and nurses, but also midwives, pharmacists, lab technicians, hospital managers and so on. WHO estimates there are around 60 million health care workers, and like any other group professionals they tend to migrate to areas where working conditions are best. Furthermore, WHO found that a quarter to two thirds of health workers interviewed in recent study expressed an intention to migrate. $^{10}$

\section{The Brain Drain Impact}

When health care workers decided to migrate it has three alternative point of views, the first is that of the migrant himself, the country of origin and the receiving country.

\section{Health care brain drain as the migrant point of view}

It is clear that the health care workers migrate to seek out for a better opportunity and a better standard of living, it cannot blame on them personally that when they are decided to migrate for their own environment. The migrate of health worker has affected to the lack of health care professional and medical teacher in the medical schools, this fact can be seen from which is happen in sub saharan Africa, there are 11 countries in sub saharan Africa and those countries without any medical schools and from 24 have only one. As this happen, the health care professional only get such a poor salary, while they are needed to feed their family and want to have a better standard of living.

Another advantages the migrant can gain through their migrate is the remittances to their family and investment to their home markets. As UK survey shows that more than half of the foreign trained nurses in the receiving country reported that they regularly send money

\footnotetext{
${ }^{10}$ KasseyKissic, The "Brain Drain": Migration of Healthcare Workers out of sub-Saharan Africa, accessed at http://med.stanford.edu/schoolhealtheval/files/KissickBrainDrainFactSheetFinal.pdf. 06.06.2016
} 
to their home country. This regular remittance amounts up to a significant proportion of their total income, as the survey reported that half of the nurses sending a quarter or more of their monthly salary send back home. ${ }^{11}$

\section{The consequences to the country of origin}

In recently of 4 August 2005, South Africa was announced that they take steps to bring home some of thousands of its health professional which are working in western countries, accusing the UK, Australia, and the USA as the biggest poachers. The government sees this as an important matter to take back their health professional to train more professionals as well as improve the working conditions and salaries in South Africa, this will be a bilateral agreements between both Africa and the receiving country. ${ }^{12}$

Regarding to this fact, it can be defined that the migrate of health worker have affected the health care system in the country of origin, which caused bad effect not only to the source population so do the healthcare professional of the home country. The country of origin not just lack of the healthcare professional, but also lack of skilled to handle kind of disease that cannot be solved within barely knowledge of the healthcare professional of the home country. They are need the health care professional which are have the experiences as they think that they have learned new knowledge from the receiving country where they have working for.

In 2006 WHO estimated that there was a shortage of more than 4.3 million health professional migrate across the world with developing country hard hit. Pursuant to this report it can be stressed that the people of this particular country choosing to be health worker professional is not because the value of the profession but more because of the possibility to migrate.

\footnotetext{
${ }^{11}$ The brain drain of health professional from sub Saharan Africa to Canada, Op.Cit,p. 53

${ }^{12}$ Op.Cit, p. 14
} 
Figure 1.5 Countries with a critical shortage of health service providers (doctors, nurses and midwives)
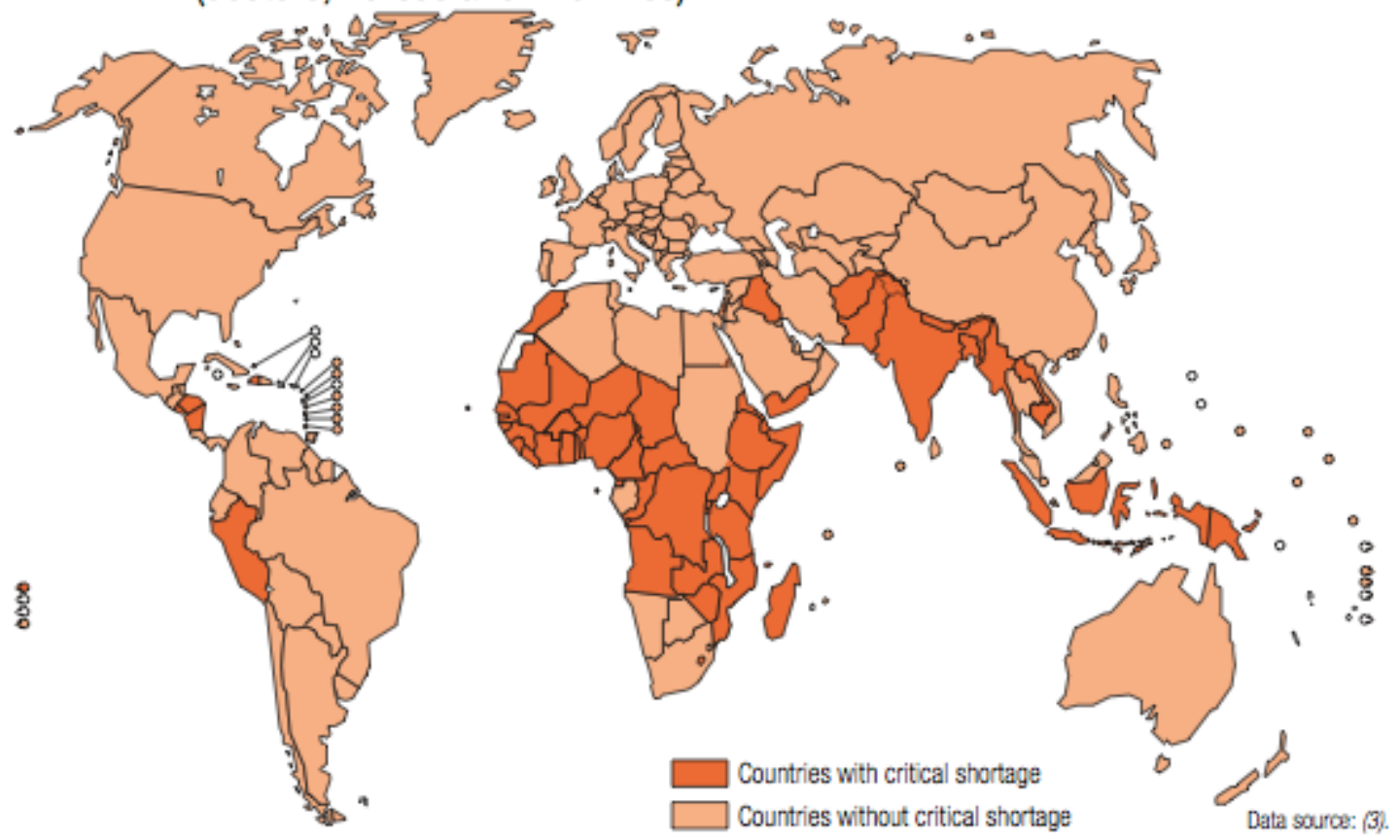

As this map shows, it can be describe that the healthcare shortages exist in the developing country, with the most notable deficit in sub Saharan Africa. ${ }^{13}$

Sub Saharan Africa can be taken as an example of the developing country that over $50 \%$ of their health worker have migrate, and an example of developing country that suffer directly impact caused of the health worker migration the most. SSA has seen a resurgence of various diseases that were thought to be receding, while public health system remains inadequately staffed. According to one report, the region needs approximately 700,000 physicians to meet the millennium development goals. ${ }^{14}$

Another direct impact of the brain drain is the government loss of the education costs to educated migrant, the loss to the home country may be greater than the cost of an emigrant's education, for the present value of his expected direct and indirect contribution to the national income in the future may exceed the cost of his education. ${ }^{15}$ Considering the government loss of cost which have spending time and money to educated the peoples it does not guarantee that they will contribute to do the worked in their home country, as mentioned above that in Sub Saharan Africa the peoples interested to become health worker is because the possibility to migrate.

Despite all of the negative impact of the migrate health worker might contribute to

\footnotetext{
${ }^{13}$ Op.Cit, p. 1

${ }^{14}$ Jonathan Crush, Op.Cit., p. 30

${ }^{15}$ Ibid, p.12
} 
the country of origin. There are some positive contribution that the migration health worker give, particularly the remittance they send montly to their family and investments in their home markets. Largely, remittances send back to support their family members and to pay off investments (principally the family home), therefore typically represent private welfare in gains and do very little to offset the public health investment losses incurred by source countries upon the emigration of health care professionals. ${ }^{16}$

In some cases, some of those who migrate from their developing area have received better education, they are subsidized by the host country in a private means. After they graduated, these students may not fulfill the potential contribution they could make to their country of origin. Most of cases in the developing country the skill people may hard to find job (jobless) even though they have degree. The country of origin may not liable the merit of salary to its educational people. The best way to solved this situation is going abroad and seeking for a good opportunity and job in the developed area. However there is a policy from developing country trying to reduce its unemployment people by send them to the developed area. This fact can be seen through the Philippine government policy that support its temporary contract worker program to reduce unemployed skilled workers to find work abroad especially to the developed area. ${ }^{17}$

\section{The consequences to the receiving country}

The benefits that the developed country gain is from the costs of the receiving country to spend within the training to the health care professional, largely this costs involving the processes required to retrain and re-credential the health worker providers from developing country, for example where most of African skilled health worker migrate to Canada, Canada needs to provide training to the health worker, as follows:

1. Assessment of existing credentials and identification of training they would still need to be on par with Canadian trained health care professionals. This matter is of considerable concern to many interviewees (particularly credentialing of those who come of own accord, i.e. not recruited)

2. Retraining individuals (skill enhancement) paid by Canada

3. Post graduate training/residency and

\footnotetext{
${ }^{16}$ Ibid, p. 53

17 Dhanajayan Sriskandarajah,Reassessing the impacts of brain drain on developing countries, accessed at http://www.migrationpolicy.org/article/reassessing-impacts-brain-drain-developing-countries 05.06.2016
} 
4. Language training. ${ }^{18}$

Foreign physicians may enter practice without any Canadian postgraduate training or may spend a certain period of time in a post graduate training residency program. In 1982, the CIHI figures the number of foreign trained physicians which enter Canada without training or post graduate training in Canada go sharply with approximately 220 individuals and decreased by 2000 with approximately 35 individuals. As this fact, it can be defined that foreign trained physicians have sufficient training when arriving to Canada and it is indicated that Canada has a little more cost which related to training the foreign trained physicians. ${ }^{19}$

Another benefits is that the foreign skilled health worker experience, as the result of the research that some correspondents describe that African nurses have a wealth of experience and sometimes greater scope of practice, this matter considered from the African context. Moreover their competencies which they were educated under a similar system, so Canada gain is really fairly high benefits through it. ${ }^{20}$

Generally, the brain drain also brings the benefits to the receiving country including the grater social benefits, better welfare and increased social services for citizens which flow from migration, and are the result of a larger tax base and greater social security funds, higher level of entrepreneurship and a younger population in demographic terms. As indicated by the World bank : "there is considerable support for the view that migrants create new business, jobs and fill labor market gaps, improving productivity and reducing inflationary pressures.",21

\section{The Brain Drain Under Human Rights Perspective}

\section{The brain drain rights as fundamental human rights}

Fundamental human rights are stated generally under UDHR, stressed that human rights are inherent to all human beings, there must be an equality in treatment without any discrimination whatever our nationality, place or residence, sex, nationality or ethnic origin, color, religion, languages are. Everybody entitled under human rights which are interrelated, interdependent and indivisible.

UDHR can be understood as the center of the human rights, it is a declaration and not

\footnotetext{
${ }^{18}$ Op.Cit, p. 50

${ }^{19}$ Ibid, p. 51

${ }^{20}$ Ibid, p.49

${ }^{21}$ Office of the UN high commission for human rights, Migration and Development a Human Rights Approach, p. 9
} 
a treaty, while it place duties on states it had no legal force. Means to say that this treaty is not bound to any state, therefore be general to general assembly to draw up a charter of human right which should not merely enumerate those rights, but also set forth how they could be established, their limitations and the national and international guarantees in respect of them. ${ }^{22}$

Relation between medical brain drain and human rights is stated under article 13 UDHR, that are:

1) Everyone has the right to freedom of movement and residence within borders of each state

2) Everyone has the right to leave any country, including his own and to return to his country. $^{23}$

Pursuant to this article all people are given the freedom of movement, including the health care worker. They free to decided when and where to go including leaving their country of origin to other state, and they also free to return to their home country.

The human rights aspects of brain drain is not only related to the freedom of movement of the health care worker. There are two clusters related, that are labor right and the rights to the health services. Labor right that can not provided since the poor terms and conditions of work in the developed country are primary cause of the movement of the health care workers. The right to health services that is undermined in poorer countries of origin and strengthened in richer receiving country.

\section{The brain drain facing human rights problem (study case in Sub Saharan Africa (SSA)}

In sub Saharan Africa, there are 34 countries have fewer than 10 doctors per 100.000, while OECD countries average 222 doctors for the same population. Infected by the "HIV/AIDS" epidemic increases the work burden, sickening and killing health workers and sigmatising those who care for patients. In 1999, Ghana lost more nurses than it retained. In Malawi, only 1,824 of 6,620 established posts for nurses were filled. Between $30 \%$ and $50 \%$ of South Africa health graduates each year leave South Africa for the UK and USA, and the needs of both countries will increase over the next decade. When a country has fragile health system, with the consequences measured in lives lost. In these circumstances, the calculus of

\footnotetext{
${ }^{22}$ Marie BenedictteDembour and Tobias Kelly (2011), Are human rights for migrants? (critical reflections on the status of irregular migrants in EUROPE and the United States, Routledge, p. 8

${ }^{23}$ Article 13 UDHR.
} 
international migration shifts from brain drain/gain to fatal flows. ${ }^{24}$

Regarding to this fact, it can be discussed 3 points of view :

1. The freedom of movement which are drive the people of sub Saharan Africa to migrate, no rules can prohibited these peoples to migrate out, as seen from the circumstances in the SSA there are strong push and pull factors that push the peoples to migrate seek out for a better opportunities in the developed country, which are main destination country are UK and USA.

2. HIV/AIDS phenomenon which are push the health care worker to migrate from SSA, it infected the health worker which are taking care to the patients of HIV/AIDS, the fact taking picture with what happen particularly in Ghana where they lost more nurses then they can retained. Regarding to this push factors, the health care worker will consider to migrate to save their life and to gain more benefits in the developed area.

3. The migrate of the health care worker affected the health care system in the country of origin, as it describe in the case above it has affected generally to the whole part of SSA area, while the health care worker choose to migrate they are leaving their country in the crisis of health care system, including the disease will increase and affect the source people, the country of origin will lack of the health care worker, and reduction of the health teacher, And this situation compounded by the number of deaths will increase.

As the brief outline it can be simply said that the movement of the health care worker as the violate to the structural human right, this point departure from the effect that affected source population that they in a poverty circumstances, where the people in the source country are suffer in the health care access and aggravated by the deaths and HIV/AIDS which is affected the most population of the source country.

As a result of this statement, the pioneering professor of peace and conflict research, Johan Galtung, was the first to coin the phrase of "structural violence", in the first line Galtung defines violence as avoidable impairment of fundamental human needs or to put it in more general terms, the impairment of human life, which lowers the actual degree to which someone is able to meet their needs below that which would otherwise be possible. Galtung offers an example, if personal died from tuberculosis in the eighteen century it would be hard to conceive of this violence since it might have been quite unavoidable, but when he dies from it today, despite all the medical resources in the world the violence is present according

${ }^{24}$ Op.Cit., p. 17 
the definition. ${ }^{25}$

According to the definition and example Galtung has describe, can be concluded that the medical brain drain have violent the structural human rights, as it evidence shows in recently most of health care worker in Africa leaving their country while the source population facing the problem with death and disease particularly HIV/AIDS. However, even though the data proof that the poverty arises in Afrika, health care acces system in a messy circumstances, it is not that easy to pointed all of the failure only to the medical brain drain. It can be argues that the medical brain should not be construed as a human rights violation via the actions of individual and collective agents. the agent centred of human rights responsibility fails to capture the structural features that enable and constrain the actions of the alleged violators in a morally relevant way. ${ }^{26}$ Moreover Paul farmer given the deeply understanding regarding to this violence, farmer asserts that structural violence is no the result of accident or a force majeure, they are the consequence, direct or indirect of human agency. $^{27}$

Regarding to the former statement, it can be claimed that the violence as the consequences in a direct or indirect way of a human agency, this human agency is implicated through structures that reflect an unequal distribution of power. the poverty and lack of health care access in Africa as the direct effect through this unequal distribution, the peoples migrate push by the development which cannot guarantee prosperity to the health care worker, and it directly affect the source population of disease effect.

\section{Constitution Of Who (World Health Organization) Related To The Medical Brain} Drain

WHOestimated that most of developing country which migrate to the developed area is Sub Saharan Africa (SSA), it is significant from the push and pull factors. These factors can be describe in push as the reason to migrate because of the workers concerns about lack of promotion prospects, poor management, heavy workload, lack of facilities, a declining health service, inadequate living conditions, and high levels of violence and crime. They are pull of expected for a better remuneration, upgrading qualifications, gaining experience, a

25 Kathleen Ho'o, Structural Violence as a Human Rights Violation, Page 3 accessed at http://projects.essex.ac.uk/ehrr/V4N2/ho.pdf 04.06.2016.

26 Aszter Kollar Brain Drain as structural Human rights violation.https://www.academia.edu/3528333/Medical_Brain_Drain_as_Structural_Human_Rights_Violatio n. accesed at 9.01.2016.

${ }^{27}$ Kathleen Ho,o,OP.Cit. 
safer environment and family related matters. ${ }^{28}$

Health workers' reasons to migrate in four African countries

(Cameroon, South Africa, Uganda and Zimbabwe)

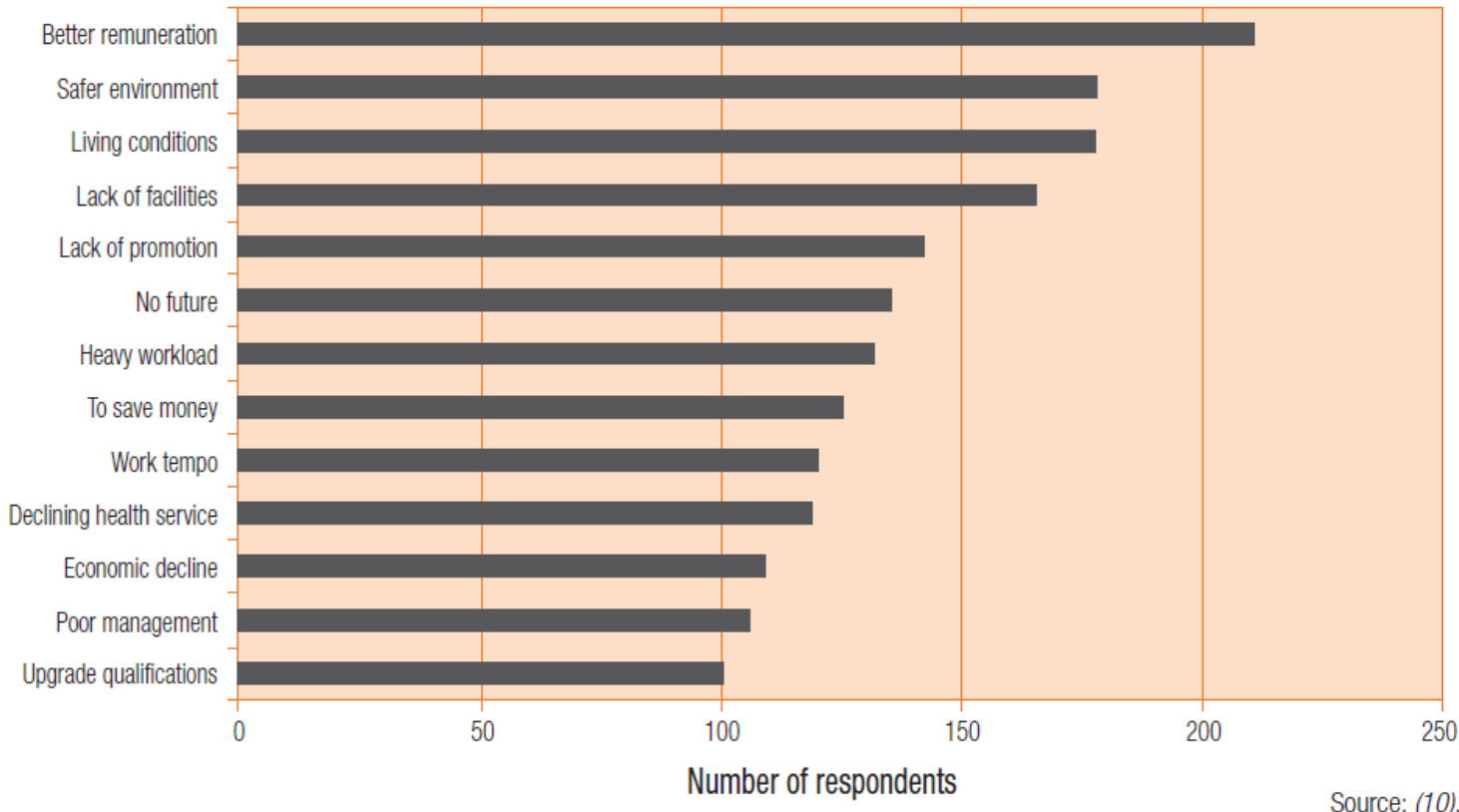

Doctors trained in sub-Saharan Africa working in OECD countries

\begin{tabular}{|c|c|c|c|}
\hline \multirow[b]{2}{*}{ Source country } & \multirow[b]{2}{*}{$\begin{array}{r}\text { Total doctors in } \\
\text { home country }\end{array}$} & \multicolumn{2}{|c|}{ Doctors working in eight OECD recipient countries ${ }^{a}$} \\
\hline & & Number & $\begin{array}{r}\text { Percentage of home } \\
\text { country workforce }\end{array}$ \\
\hline Angola & 881 & 168 & 19 \\
\hline Cameroon & 3124 & 109 & 3 \\
\hline Ethiopia & 1936 & 335 & 17 \\
\hline Ghana & 3240 & 926 & 29 \\
\hline Mozambique & 514 & 22 & 4 \\
\hline Nigeria & 34923 & 4261 & 12 \\
\hline South Africa & 32973 & 12136 & 37 \\
\hline Uganda & 1918 & 316 & 16 \\
\hline $\begin{array}{l}\text { United Republic of } \\
\text { Tanzania }\end{array}$ & 822 & 46 & 6 \\
\hline Zimbabwe & 2086 & 237 & 11 \\
\hline Total & 82417 & 18556 & Average 23 \\
\hline
\end{tabular}

a Recipient countries: Australia, Canada, Finland, France, Germany, Portugal, United Kingdom, United States of America.

\section{WHO strategies to manage the negative impact of the brain drain}

as the negative impact of the medical brain drain, the WHO manage their strategies into three steps, first is according to the source country, second is to the receiving country.

1. Source country

\footnotetext{
${ }^{28}$ WHO , Working Together For Health the WHO, report 2006, p. 101, at http://www.who.int/whr/2006/whr06_en.pdf?ua=1
} 
Source country can consider in to ways to solve the problem of the health worker migration, the first is to provide the skilled health worker for their place of employment and another one is to give the easiest acces for the health worker to return back to the resource country.

\section{a. Adjust training to need and demands}

Even in the face of continued migration, the source country should be liable to provide training to the health worker particularly focused on local conditions, which can help them to limit attrition. From longstanding efforts, lessons to improve health worker in rural areas suggested to trained local workers, in languages and in skill, it can helps to reduce exists health workers.

For examples Philippines has been training health workers, especially nurses for export for many years, they constitute $76 \%$ of foreign nurse graduated in the united states. Likewise Cuba has exported thousands of health workers to the philippinnes through bilateral agreement. ${ }^{29}$

b. Improve local conditions

By giving the easisest access to the health worker who migrate to the receiving country is one of another strategic WHO suggested to do of the country of origin, as result of the surveys that most of the medical brain drain wants to return back to the home country. As an example Philippines has regulated thespecial provision not only about but also in their home return. ${ }^{30}$

\section{Receiving country}

The receiving country should taking care of the foreign health worker which choose to migrate to their area, including concern to their right, welfare and responsive to edverse consequences in source countries associated with their absence.

\section{a. Ensure fair treatment of migrant workers}

In respect to the human rights, that the receiving country have to be followed in respect to the migrant rights as a human right, giving the equal treatment without any discrimination between the foreign health worker and the citizen. As the embodiment of this statement that the receiving country according to the recruited on terms and conditions equal to those of locally recruited staff, it is very crucial to place that identify and deal with racism among staff and clients.

\footnotetext{
${ }^{29}$ Ibid,p. 102

${ }^{30}$ Ibid, p. 103
} 


\section{b. Adopt responsible recruitment policies}

The receiving country responsibility is to make sure that recruitment of workers from the shortages workforce country is sensitive to the adverse consequences. The significant investment made in training health care professionals and the immediate impact of their absence through migration must figure more prominently as considerations among prospective employers and recruitment agencies. ${ }^{31}$

c. Provide support to human resources in resource country

Many recipient countries are also providers of overseas development assistance for health. Through this structure, support could be more directly targeted to expanding the health care worker, not only to reduce the impact outgoing migration but also to overcome the human resources constraints to achieving the health related millennium development goals (MDGS). ${ }^{32}$

\section{HIV/AIDS issue}

Regardingthe WHO report on 2006, estimated that in several southern Africa countries death from HIV/AIDS, this caused the worker to exits from the workforce. For those who are stay in the source country are facing diffulty in treating all of the HIV/AIDS sufferer and lack of the facilty to treat them. As in turn, these working conditions make the health worker fuel low morale, exhausted and absenteism. According to this fact many countries making the provision to ensure the treatment access to worker who become infected with HIV, they were infected linked by the unsafety of the needle stick injuries, post exposure prophylaxis and lack of the protective equipment.

In 2005 the InternationalLabour organization and WHO agreed to joint guidelines designed to help workers involved in the global struggle against HIV/AIDS to stay healthy. ${ }^{33}$ Preparing the workforce for the growing burden of chronic disease and injuries

As the big matter which the MDGS face is the impact of the chronic disease which are the most contributor to deaths and defect, This matter caused by the consequences of the unstable economy circumstances.

Backgrounded by the fact mostly happen in Africa, which are now using a set of simplifie operational guidelines from WHO's integrated management of adult and adolescent illness (IMAI) to train health workers, currently this guideline using by 25 countries in

\footnotetext{
${ }^{31}$ Ibid, p. 103

${ }^{32}$ Ibid, p. 104

${ }^{33} \mathrm{Ibid}$, p. 52
} 
Afrika. It is determine the tasks required for chronic HIV/AIDS prevention, care and antiretroviral therapy as well as tuberculosis care and co-management of TB/HIV/AIDS patients. Which allow the interventions to be delivered by the nurses, clinical officers, midwives and various cadres of medical assistants, which are working together in a clinical team in the hospital outpatient facility or in peripheral health centres. ${ }^{34}$

\section{CONCLUSION}

Brain drain can be understood as the movement of the skilled people from less developed area to the developed area, to seek out for a better quality of life and opportunities. The people migrate caused by the lack development of their home country, and this reason derived them to migrate to the developed area where they may get the new opportunity.

Since the medical Brain Drain migrate, it is arises a new problem to the source country especially to the population, it affects them in many ways such as unbalance of the health care system, it affects many disease developed and ended the people to death because the country lack of the health care professional worker.

According to what happen in Sub Sahara Africa where a lot of people die just because a simple illness, it is issued one question related to human rights which are categorized them into one the structural human right violence which is based on the effect of the health care worker who migrate and leave the source country in poverty. Despite that the health worker cannot be blame to fight for their right which is entitled under Article 13 UDHR that giving them freedom of movement and to return back to their home country.

Further WHO with its new guidance tried to solvethe impact of the medical brain drain with the suggestion to the source country and the receiving country, particularly in Africa through some guidance of the health worker there, which are now followed by 25 country in Africa.

\section{Bibliography}

Amy Schnidman, (2006), The Global Effects Of The Brain Drain on health care system, Vol

3, Georgetown university, https://blogs.commons.georgetown.edu/journal-of-healthsciences/issues-2/previous-volumes/vol-3-no-1-march-2006/the-global-effects-of-thebrain-drain-on-health-care-systems/

\footnotetext{
${ }^{34}$ Ibid, p. 233
} 
Volume 2, Issue 1, April 2018 Open Access at: http://unramlawreview.unram.ac.id/index.php/ulr/user Aszter $\begin{gathered}\text { Kollar } \\ \text { violation,https://www.academia.edu/3528333/Medical_Brain_Drain_as_Structural_Hu }\end{gathered}$ violation,https://www.academia.edu/3528333/Medical_Brain_Drain_as_Structural_Hu man_Rights_Violation

Brian Keeley, (2009), International Migration (The human face of Globalization), OECD publishing.

Ceylanyeginsu, In turkey a Syrian child has to work to survive, accessed at www.nytimes.com

Dhanajayan Sriskandarajah, Reassessing the impacts of brain drain on developing countries, accessed at http://www.migrationpolicy.org/article/reassessing-impacts-brain-draindeveloping-countries.

Jonathan Crush, The brain drain of health professionals from Sub Saharan Africa to Canada (series editor), SAMP

Kassey Kissic, The "Brain Drain": Migration of Healthcare Workers out of sub-Saharan Africa, accessed at http://med.stanford.edu/schoolhealtheval/files/KissickBrainDrainFactSheetFinal.pdf

Kathleen Ho, Structural Violence as a Human Rights Violation, accessed at http://projects.essex.ac.uk/ehrr/V4N2/ho.pdfOwen Barde, What is development?, Center for Global development, http www.cgdev.org

Marie Benedictte Dembour and Tobias Kelly, (2011), Are human rights for migrants? (critical reflections on the status of irregular migrants in EUROPE and the United States), Routledge.

Office of the UN high commission for human rights, Migration and development a human rights approach

S Watanabe, The brain drain from Developing to developed countries

Sunita Dodani, Ronald E laporte, Brain drain from developing countries : how can brain drain be converted into wisdom gain?http://www.ncbi.nlm.nih.gov/pmc/articles/PMC1275994/

WHO Report 2006 , Working Together For Health, accessed at http://www.who.int/whr/2006/whr06_en.pdf?ua=1 